Article

\title{
Intranasal Immunization of Mice with Multiepitope Chimeric Vaccine Candidate Based on Conserved Autotransporters SigA, Pic and Sap, Confers Protection against Shigella flexneri
}

\author{
Yrvin León ${ }^{1}$, Lionel Zapata ${ }^{2}$, Raúl E. Molina ${ }^{1}$, Gaj Okanovič ${ }^{3}$, Leonardo A. Gómez ${ }^{1}$, \\ Carla Daza-Castro ${ }^{1}{ }^{1}$, Manuel Flores-Concha ${ }^{1}$, José L. Reyes ${ }^{1}$ and Angel A. Oñate ${ }^{1, *}$ \\ 1 Laboratory of Molecular Immunology, Department of Microbiology, Faculty of Biological Sciences, \\ Universidad de Concepción, Concepción 4030000, Chile; yrvinln@gmail.com (Y.L.); \\ ramolina@udec.cl (R.E.M.); leonardogomez@udec.cl (L.A.G.); carla.dazac@gmail.com (C.D.-C.); \\ manuelflores@udec.cl (M.F.-C.); josereyes@udec.cl (J.L.R.) \\ 2 Laboratory of Recombinant Biopharmaceuticals, Department of Pharmacology, Universidad de Concepción, \\ Concepción 4030000, Chile; lionelzv@gmail.com \\ 3 Faculty of Medicine, University of Ljubljana, Ljubljana 1500, Slovenia; gaj.okanovic@gmail.com \\ * Correspondence: aonate@udec.cl
}

Received: 17 July 2020; Accepted: 11 September 2020; Published: 1 October 2020

check for updates

\begin{abstract}
Shigellosis is a diarrheal disease and the World Health Organization prompts the development of a vaccine against Shigella flexneri. The autotransporters SigA, Pic and Sap are conserved among Shigella spp. We previously designed an in silico vaccine with immunodominat epitopes from those autotransporters, and the GroEL protein of $S$. typhi as an adjuvant. Here, we evaluated the immunogenicity and protective efficacy of the chimeric multiepitope protein, named rMESF, in mice against lethal infection with $S$. flexneri. rMESF was administered to mice alone through the intranasal (i.n.) route or accompanied with Complete Freund's adjuvant (CFA) intradermically (i.d.), subcutaneously (s.c.), and intramuscular (i.m.), as well as with Imject alum (i.m.). All immunized mice increased IgG, IgG1, IgG2a, IgA and fecal IgA titers compared to PBS+CFA and PBS+alum control groups. Furthermore, i.n. immunization of mice with rMESF alone presented the highest titers of serum and fecal IgA. Cytokine levels (IFN- $\gamma$, TNF- $\alpha$, IL-4, and IL-17) and lymphocyte proliferation increased in all experimental groups, with the highest lymphoproliferative response in i.n. mice immunized with rMESF alone, which presented $100 \%$ protection against $S$. flexneri. In summary, this vaccine vests protective immunity and highlights the importance of mucosal immunity activation for the elimination of S. flexneri.
\end{abstract}

Keywords: bacillary dysentery; Shigella flexneri; mucosal immunity; autotransporters; GroEL; multiepitope chimeric vaccine

\section{Introduction}

Shigella spp. are Gram-negative, non-motile, non-spore-forming, facultative anaerobic bacilli bacteria that invade the human colonic epithelium and cause bacillary dysentery or shigellosis [1]. This pathogen has a very low infectious dose of about 10-100 bacteria cells [1], mainly affecting children under five years of age [2], but also all age groups during outbreaks [3,4]. There are four serogroups of Shigella: S. dysenteriae (12 serotypes), S. flexneri (six serotypes), S. boydii (18 serotypes), and S. sonnei (one serotype), respectively [5]. The Global Burden of Disease estimates that Shigella is the second common cause of diarrheal deaths, with 164,300 annual deaths worldwide [6,7]. The main serogroup 
correlated with shigellosis in developing countries is S. flexneri [5]. The urgency of a vaccine against Shigella is needed by the increase of antibiotic resistance registered in many countries $[8,9]$, prompting the World Health Organization to prioritize the development of a safe and effective vaccine against S. flexneri $[2,10,11]$.

Most of the vaccine candidates evaluated against Shigella present a weak immune response [12], they and confer inadequate broad protection among the different serotypes of Shigella [13,14]. An approach for overcoming this current problem in Shigella vaccines is the use of conserved antigens between the different serotypes of Shigella strains, like Ipas proteins, which were used as vaccines in mouse models, or in silico analyses with the conserved proteins: SigA, Pic, and Sap [15,16].

SigA, Pic, and Sap are autotransporters encoded in the pathogenic island (PAI) SHI-1 of S. flexneri. SigA, and Pic are involved in the mechanisms of virulence and natural induction of IgG immunoglobulins in the host [17-19]. SigA causes severe damage to the Hep-2 cell line, and in volunteers infected with $S$. flexneri 2 a, there are high levels of IgG antibodies against the protein [18]. Pic has mucinase activity and is considered the unique immune-modulating bacterial virulence factor in Shigella, comparing with a pic mutant that produces greater inflammation in the guinea pig keratoconjunctivitis infection model [19]. It is interesting to note that Pic from enteroaggregative E. coli (EAEC) induce high levels of IgG and IgM antibodies during a natural EAEC infection in children [20]. Sap, is a protein that has $87 \%$ identity with the amino acid sequence of Ag43 from E. coli, a protein that is involved in mechanisms of virulence, such as adhesion, aggregation, biofilm formation, and host immune evasion $[17,21]$. Hence, the described autotransporters could be considered to be targets in the development of vaccines against Shigella and some E. coli pathogenic specie [16].

Heat shock proteins (HSPs) are highly conserved proteins in bacteria and mammals [22]. These proteins interact with toll-like receptors (TLR), such as TLR2 and TLR4, and they stimulate the innate immune response [23]. Thus, HSPs, like GroEL (HSP 60) protein of Salmonella Typhi [24,25], have been successfully used as antigens [26] and adjuvants in the development of vaccine candidates [27]. The adjuvant capacity of GroEL has been evaluated in a recombinant domain-GroEL fusion protein with the conserved virulence protein IpaB of Shigella [28]. Mice immunized with the fusion protein as compared with mice without GroEL showed an increase in Th1 and Th2 response and high levels of protection in a Shigella lethal infection assay [28]. Moreover, the use of GroEL in fusion protein has the advantage of reducing the cost of vaccine production and simplifying manufacturing process and formulation $[26,28,29]$.

Given this information and in consideration with a $S$. flexneri vaccine targeted at passenger domains of SigA, Pic and Sap autotransporter proteins, we implemented an in silico vaccine that was based on analysis of a chimeric multiepitope protein designed with highest immunogenic and antigenic epitopes bound to GroEL adjuvant [16]. In this work, we demonstrate that the immunization of mice with chimeric antigens displaying selected epitopes fused to GroEL induce an immune response and high protective efficacy against $S$. flexneri.

\section{Materials and Methods}

\subsection{Mice}

Six-week-old female BALB/c mice were provided by the Instituto de Salud Pública, Santiago, Chile. The animals were maintained in the Laboratory of Molecular Immunology, University of Concepcion, Chile. They were handled in all experiments while using standard conditions approved by the Bioethics and Safety Committee of the Faculty of Biological Sciences. Food and water were given ad libitum.

\subsection{Growth Conditions of Bacterial Strains}

Shigella flexneri 2a strain was kindly facilitated by Dr. Cecilia Toro of the Instituto de Ciencias Biomédicas, Universidad de Chile, Chile. Shigella was grown in tryptic soy broth (TSB, BD Difco ${ }^{\mathrm{TM}}$ ) 
at $37^{\circ} \mathrm{C}$. Colonies bearing the virulent plasmid pINV were selected on tryptic soy agar (TSA, EMD Millipore, Burlington, MA, USA) with $0.02 \%$ Congo red. E. coli DH5- $\alpha$ and E. coli BL21 strains used for cloning and expression, respectively, were grown in Luria Bertani (LB) medium (BD Difco ${ }^{\mathrm{TM}}$ ) at $37^{\circ} \mathrm{C}$ with $50 \mu \mathrm{g} / \mathrm{mL}$ ampicillin where required.

\subsection{Gene Construction and Cloning}

We had previously designed an in silico gene construction with the sequences of the HSP GroEL of $S$. Typhi and the highly antigenic epitopes that were selected from three passenger domains of SigA, Pic, and Sap autotransporters of S. flexneri. These sequences were linked together with different proper linkers, EAAAK, GSGSAAY, and HEYGAEALERAG, according to the in silico design of vaccine that was described in León et al. [16]. The constructed gene was named multiepitope $S$. flexneri (MESF). It was optimized for $E$. coli expression and cloning into the vector pUC57 with two restriction sites SmaI and KpnI added in the $3^{\prime}$ and $5^{\prime}$ ends, respectively (Biomatik Corporation, Wilmington, DE, USA). The construct was named pUC57-MESF. E. coli DH5- $\alpha$ was transformed with pUC57-MESF and the DNA plasmid was isolated with Wizard ${ }^{\circledR}$ Plus SV Minipreps DNA Purification System as per manufacturer instructions (Promega, Madison, WI, USA). This was used to clone the MESF fragment into the vector $\mathrm{PQE}-80 \mathrm{~L}$ (Addgene, Watertown, MA, USA) that has a $6 \mathrm{xHis}$ tag $5^{\prime}$ to the MCS site. The recombinant pQE-80L-MESF was electroporated into E. coli B21 and clones carrying the plasmid were screened using antibiotic selection.

\subsection{Expression, Isolation and Purification of the Chimeric Fusion Multiepitope Protein}

E. coli BL21 colonies bearing the pQE-80L-MESF were cultured in LB medium that was supplemented with ampicillin until $\mathrm{OD}_{600}$ of 0.6. Gene expression was induced with $1 \mathrm{mM}$ isopropylthiogalactoside (IPTG) for $4 \mathrm{~h}$ at $37^{\circ} \mathrm{C}$, followed by centrifugation at $6000 \times \mathrm{g}$ at $4{ }^{\circ} \mathrm{C}$ during $10 \mathrm{~min}$. The pellet was suspended in lysis buffer containing Tris $50 \mathrm{mM}, \mathrm{NaCl} 200 \mathrm{mM}$, Imidazole $5 \mathrm{mM}, \mathrm{pH} 7.0$, and maintained under $4{ }^{\circ} \mathrm{C}$ for $10 \mathrm{~min}$. The cellular suspension was passed five times through high pressure condition while using a French press (Avestin, Ottawa, ON, Canada) with $8.2 \times 10^{7} \mathrm{~Pa}$ under $4{ }^{\circ} \mathrm{C}$. Subsequently, the suspension was centrifuged at $6000 \times g$ at $4{ }^{\circ} \mathrm{C}$ for $10 \mathrm{~min}$. and the proteins in the soluble and insoluble fractions were evaluated and observed by sodium dodecyl sulphate polyacrylamide gel electrophoresis (SDS-PAGE) stained with Coomassie blue. The expressed fusion protein was confirmed through western blot by probing with IgG primary anti-Hisx6 tap and secondary anti-IgG HRP conjugated antibodies (Santa Cruz, Dallas, TX, USA). Once the expression of this protein was confirmed, the soluble fraction was analyzed by metal affinity chromatography via Ni-NTA column (ÄKTAprime, General Electric, Boston, MA, USA). The protein was eluted using elution buffer of Urea $8 \mathrm{M}$, Tris- $\mathrm{HCl} 20 \mathrm{mM}, \mathrm{NaCl} 200 \mathrm{mM}$, Imidazol 200-250 mM, pH 8.0. The eluted solution was dialyzed at $4{ }^{\circ} \mathrm{C}$ in buffer containing $50 \mathrm{mM}$ Tris and $1 \mathrm{mM}$ EDTA and concentrated (Amicon ${ }^{\circledR}$ Ultra-4 Centrifugal Filter Units, Merck Millipore, Germany). The concentration of total protein was measured through the BCA method (Pierce ${ }^{\mathrm{TM}}$ BCA Protein Assay Kit, Thermo Fisher Scientific Inc., Waltham, MA, USA). The recombinant protein obtained (rMESF) was analyzed and confirmed by SDS-PAGE electrophoresis and western blot, as described above.

\subsection{Immunization of Mice}

Six-weeks old female BALB/c mice were randomly distributed into five groups ( $\mathrm{n}=10$ per group) in different cages for the different routes of immunization. Group I was intranasally immunized (i.n.) with $25 \mu \mathrm{L}$ of rMESF ( $25 \mu \mathrm{g} /$ mouse, group rMESF), group II was injected intramuscularly (i.m.) with a mix of $50 \mu \mathrm{L}$ of rMESF ( $25 \mu \mathrm{g} /$ mouse) and $50 \mu \mathrm{L}$ of Imject ${ }^{\mathrm{TM}}$ alum adjuvant (Thermo Fisher Scientific, Waltham, MA, USA) (group rMESF+alum), group III was injected intradermally (i.d.) with a mix of $50 \mu \mathrm{l}$ of recombinant protein $(25 \mu \mathrm{g} /$ mouse) and $50 \mu \mathrm{L}$ complete Freund's adjuvant (CFA, Sigma-Aldrich, St. Louis, MO, USA) (group rMESF+CFA). Subsequently two booster doses were given to all experimental mice groups on the 14th and 28th days after the first immunization. However, in the 
case of the group III, the subsequent two boosters were applied through subcutaneous (s.c.) and i.m. routes, respectively, with incomplete Freund's adjuvant (IFA) on the 14th and 28th days. Two control mice groups were injected with phosphate Buffer saline (PBS) plus Imject ${ }^{\mathrm{TM}}$ alum adjuvant (group IV, PBS+alum) and CFA (group V, PBS+CFA), respectively. A scheme is given with the immunization strategy that was used in this study (Figure 1).

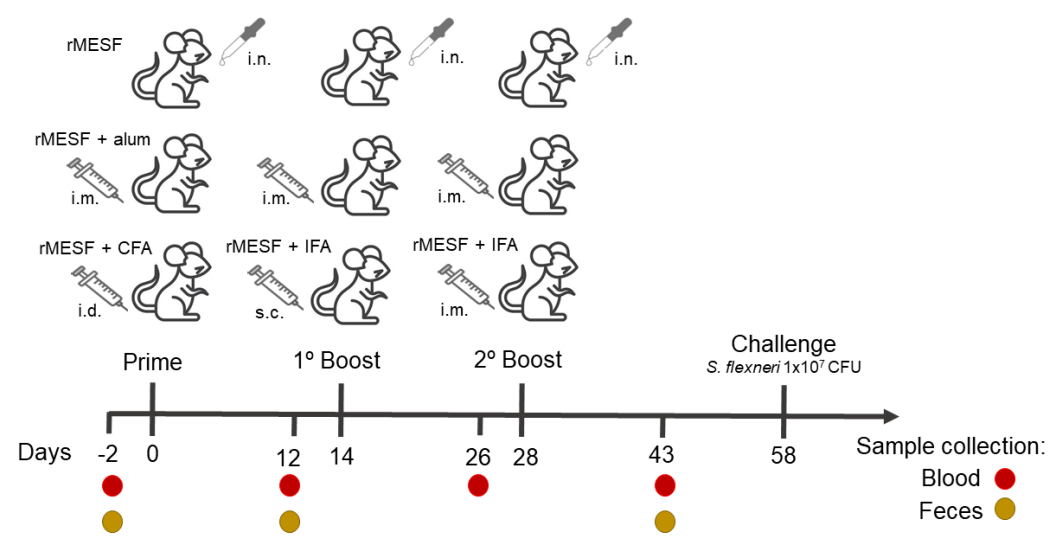

Figure 1. Immunization strategy and sample collection. Days of vaccine administration, adjuvants and routes are shown. The challenge assay was developed 30 days after the last immunization. Blood and feces collection are represented in red and golden brown circles, respectively. For more details of control groups read the text. rMESF, recombinant multiepitope $S$. flexneri protein. CFA, complete Freund's adjuvant. IFA, incomplete Freund's adjuvant. Alum, Imject ${ }^{\mathrm{TM}}$ alum adjuvant. i.n., intranasal. i.m., intramuscular. s.c., subcutaneous.

\subsection{Determination of Specific Antibodies in Peripheral Blood}

Blood was drawn from the tail of each mouse from all five groups, two days before the first immunization, 12 days after the first and second immunizations, and 15 days after the last immunization, in order to evaluate the humoral immune response. The blood was centrifuged, and serum was isolated for specific IgG, IgG1, IgG2a, and IgA detection by Enzyme-Linked Immunosorbent Assay (ELISA). Briefly, 96-well plates were coated with $1 \mu \mathrm{g}$ of the rMESF protein diluted in $200 \mu \mathrm{L}$ of coating buffer (0.05 $\mathrm{M}$ carbonate-bicarbonate, $\mathrm{pH}$ 9.6). After overnight incubation at $4{ }^{\circ} \mathrm{C}$, the plates were washed three times with PBS-0.05\% Tween-20 (PBST) and blocked with PBS 0.8\% gelatin for $2 \mathrm{~h}$ at $37^{\circ} \mathrm{C}$. Following blocking, the plates were washed with PBST three times, and each well was incubated with serial dilution of the serum from mice at $37^{\circ} \mathrm{C}$ for $2 \mathrm{~h}$. After washing three times with PBST, the plates were incubated for $1 \mathrm{~h}$ at room temperature with secondary antibodies rabbit anti-mouse IgG/IgG1/IgG2a or IgA (1:2000), conjugated to horseradish peroxidase (Serotec, Oxford, UK). Then $200 \mu \mathrm{L}$ of the substrate TMB $\left(3,3^{\prime}, 5,5^{\prime}\right.$-Tetramethylbenzidine) $/ \mathrm{H}_{2} \mathrm{O}_{2}$ (BD Biosciences, San Jose, CA, USA) was added and incubated in the dark for $30 \mathrm{~min}$. at room temperature (RT), and the reaction was stopped by adding $50 \mu \mathrm{L} \mathrm{H}_{2} \mathrm{SO}_{4} 2 \mathrm{~N}$. The plates were read at $\mathrm{OD}_{450} \mathrm{~nm}$ using VictorX3 (PerkinElmer, Waltham, MA, USA). The antibody titers were expressed as mean \pm standard deviation (SD) of $\log _{10}$ of the last reciprocal serum dilution above cut-off. The cut-off values were calculated, as described by Frey et al. [30].

\subsection{Secretory $\operatorname{Ig} A$ Determination}

The level of secretory IgA (sIgA) was determined in the feces of immunized and control mice [31]. Feces were collected, weighed, homogenized, and diluted to $0.1 \mathrm{~g} / \mathrm{mL}$ with PBS containing $0.1 \%$ sodium azide and $1 \mathrm{mM}$ of phenylmethylsulfonyl fluoride (PMSF). Fecal suspension was centrifuged at $15,000 \times g$ for $5 \mathrm{~min}$. at $4^{\circ} \mathrm{C}$, the supernatant fluid was recovered and again centrifuged at $15,000 \times g$ for $15 \mathrm{~min}$. at $4^{\circ} \mathrm{C}$ and stored at $-80^{\circ} \mathrm{C}$ until used. The specific IgA antibody levels were measured by 
ELISA with anti-IgA antibody (Thermo Fisher Scientific, Waltham, MA, USA), as previously described. The antibody titers were expressed as mean \pm standard deviation (SD) of $\log _{10}$ of the last inverse serum dilution above cut-off. The cut-off values were calculated, as described by Frey et al. [30].

\subsection{Lymphocyte Proliferation}

Five mice per group were euthanized 30 days after the administration of the last immunization, and their spleens were removed under aseptic conditions. The spleens were used to prepare single-cell suspensions by mechanical disaggregation, and the erythrocytes were lysed using ammonium-chloride-potassium (ACK) buffer [32]. The cells were then washed with RPMI 1640 medium (Gibco ${ }^{\mathrm{TM}}$, Life Technologies) and used to evaluate the lymphocyte proliferation in response to the chimeric multiepitope rMESF. Splenocytes suspended in RPMI medium that were supplemented with 10\% heat-inactivated fetal bovine serum (Thermo Fisher Scientific, Waltham, MA, USA) and antibiotic/antimycotic solution (100 UI penicillin, $100 \mu \mathrm{g} / \mathrm{mL}$ streptomycin, and $0.25 \mu \mathrm{g} / \mathrm{mL}$ amphotericin B), were plated in 96-well flat-bottom plates (Nunc, Denmark), at a concentration of $1 \times 10^{5}$ cells/well. The plates were sensitized with $1 \mu \mathrm{g} / \mathrm{mL}$ or $2 \mu \mathrm{g} / \mathrm{mL}$ of the chimeric protein and incubated for $72 \mathrm{~h}$ at $37^{\circ} \mathrm{C}$ under $5 \% \mathrm{CO}_{2}$. After this time, the cells were pulsed with $0.5 \mu \mathrm{Ci}$ tritiated thymidine $(3 \mathrm{H}-\mathrm{TdR})$ per well (Amersham, Life Science, London, UK) and after $8 \mathrm{~h}$ DNA radioactivity was measure using a scintillation counter Beckman LS 6500 (Beckman, Indianapolis, IN, USA). The positive and negative controls consisted of $10 \mu \mathrm{g} / \mathrm{mL}$ of concanavalin A (Promega, Madison, WI, USA) and complete RPMI 1640, respectively. Cell proliferation data were expressed as the stimulation index of triplicate cultures from a cell pool from each group. These were obtained by dividing the amount of $3 \mathrm{H}-\mathrm{TdR}$ incorporated (c.p.m.) in antigen-stimulated cell cultured divided by the c.p.m. derived from cells that were cultured without antigen [33].

\subsection{Cytokine ELISAs}

The levels of IL-4, TNF- $\alpha$, IFN- $\gamma$, and IL-17 were measured by antigen-capture ELISA. Briefly, splenocytes were adjusted to a concentration of $4 \times 10^{6}$ viable cells per $\mathrm{ml}$ in RPMI 1614 supplemented with $10 \%$ fetal calf serum (Thermo Fisher Scientific, Waltham, MA, USA) and antibiotic/antimycotic solution (100 UI penicillin, $100 \mu \mathrm{g} / \mathrm{mL}$ streptomycin, and $0.25 \mu \mathrm{g} / \mathrm{mL}$ amphotericin B). The cell suspensions were cultured in 24 well plates (Nunclon, Thermo Fisher Scientific, Waltham, MA, USA) and stimulated with the rMESF at a concentration of $1 \mu \mathrm{g} / \mathrm{mL}$ or $5 \mu \mathrm{g} / \mathrm{mL}$ or medium alone. They were incubated for $48 \mathrm{~h}$ at $37{ }^{\circ} \mathrm{C}$ under $5 \% \mathrm{CO}_{2}$ to induce, in vitro, the expression of cytokines. After this time of incubation, the supernatants were collected and cytokines were quantified by ELISA sandwich using the mouse IL-4, TNF- $\alpha$, IFN- $\gamma$, and IL-17 ELISA kits (BD Biosciences, USA), following the manufacturer instructions.

\subsection{Challenge Studies}

The protective efficacy of the candidate vaccine was evaluated in immunized groups ( $\mathrm{n}=5$ mice/group) after 30 days of the last immunization. The lethal dose of S. flexneri $2457 T\left(1 \times 10^{7}\right.$ colony forming units (CFU)/mouse) was determined by serial dilution, plating, and counting colonies [27,31]. Briefly, S. flexineri was grown in TSA with $0.05 \%$ Congo red at $37^{\circ} \mathrm{C}$, and then colonies were grown in $\mathrm{TSB}$ at $37^{\circ} \mathrm{C}$ in agitation until an $\mathrm{OD}_{600}=1$. The bacterial culture was centrifuged at $6000 \times g$ for $10 \mathrm{~min}$. and resuspended in PBS and adjusted to $5 \times 10^{5}$ bacteria/ $\mu \mathrm{L}$ for the infection. All of the groups of mice were challenged through the intranasal route with $20 \mu \mathrm{L}$, as described for the mouse pulmonary model with a lethal dose of $1 \times 10^{7}$ CFU/mouse of $S$. flexneri [34]. The mice were observed for mortality for 30 days.

\subsection{Organ Burden}

Bacterial load in lungs was measured at three and 30 days after challenge assay in the control and experimental groups, respectively [28]. Three mice per group were euthanized, and the lungs were removed in aseptic condition. The lungs were homogenized in $5 \mathrm{~mL}$ of ice-cold PBS and they were 
10-fold serially diluted. The bacterial serial dilutions were plated in LB agar at $37^{\circ} \mathrm{C}$, incubated for $18 \mathrm{~h}$, and the CFUs were counted.

\subsection{Statistical Analysis}

Specific antibodies, cytokines levels, and lymphocyte proliferation were analyzed by two-way analysis of variance (ANOVA). The protection studies were expressed using Kaplan-Meier survival curves. Multiple comparisons were tested using Tukey Honest Difference. Graphs and statistical comparisons were generated by GraphPad Prism version 5.04 Software (GraphPad Software, San Diego, CA, USA). A $p$ value of 0.05 or less was considered to be significant for all tests. All of the experiments were performed in triplicate.

\section{Results}

\subsection{Gene Construction, Cloning, and Production of the Chimeric Recombinant Multiepitope Protein}

The gene for the recombinant multiepitope S. flexneri protein (rMESF) was obtained from Biomatik Corporation and then was cloned into the pQE-80L expression vector. Total size of rMESF was $2508 \mathrm{bp}$, the complete size of pQE-80L-rMESF was 7259 bp, and the digestion products with SmaI and KpnI of the ligated vector (Figure 2A) were observed on agarose electrophoresis gel after extraction and purification from transformed E. coli BL21 (Figure 2A). The 6xHis tail is encoded in the expression vector at the 5'end of the gene. The recombinant protein was induced with $1 \mathrm{mM}$ IPTG, and the rMESF protein expression was confirmed with a SDS-PAGE electrophoresis (Figure 2B) and western blot (Figure 2C). The expression of rMESF induced with IPTG showed that this recombinant protein has a molecular weight close to $84.5 \mathrm{kDa}$. The majority of this protein was found in the soluble fraction after membrane disruption of the bacteria. Elution and purification were carried out while using Ni-NTA chromatography. The refolded, dialyzed, and concentrated protein was confirmed by SDS-PAGE electrophoresis, followed by western blot (Figure 2D).
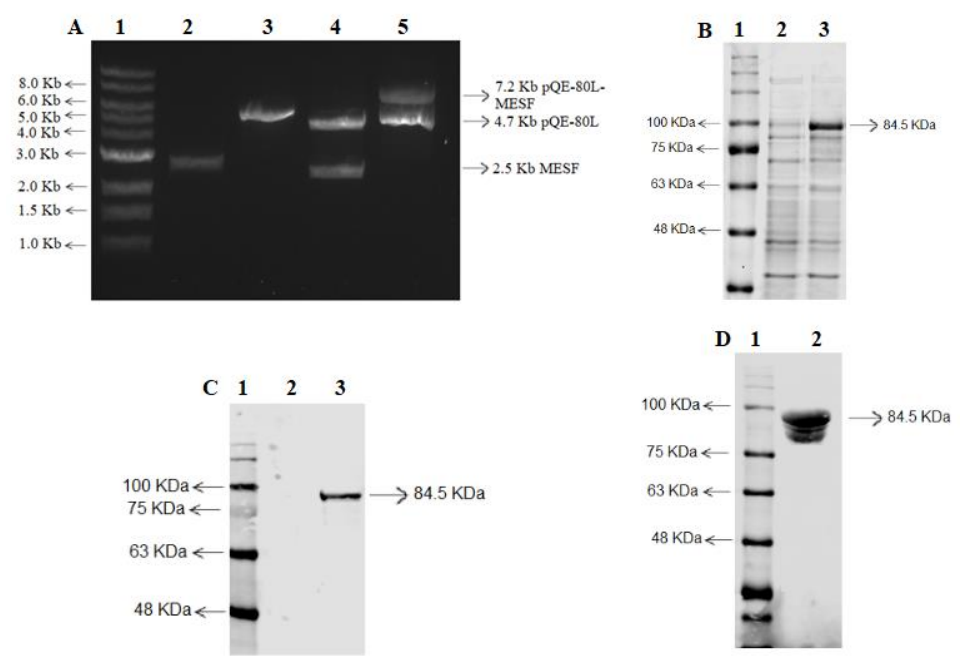

Figure 2. Cloning of chimeric gene (MESF), expression and purification of the recombinant multiepitope protein (rMESF). (A) Cloning of the MESF gene in pQE-80L expression vector with T4 ligase. Lane 1: $1 \mathrm{~kb}$ DNA ladder. Line 2: MESF gene. Line 3: pQE-80L. Line 4: product digestions of pQE-80L-rMESF with SmaI and KpnI after ligation. Line 5: full circular size of pQE-80L-rMESP (B). SDS-PAGE of the expressed rMESF in E. coli BL21 cells after the induction with $1 \mathrm{mM}$ IPTG for $4 \mathrm{~h}$ at $37^{\circ} \mathrm{C}$. Line 1 : molecular mass marker. Line 2: protein before induction with IPTG. Line 3: proteins after induction with IPTG showing the rMESF protein with $84.5 \mathrm{kDa}$. (C) Western blot confirming the expression of rMESF after the induction with IPTG. (D) Western blot confirming the presence of rMESF protein after the purification-elution by Ni-NTA affinity chromatography. IPTG, isopropylthiogalactoside; SDS-PAGE, sodium dodecyl sulfate-polyacrylamide gel electrophoresis. 


\subsection{Chimeric Multiepitope Protein rMESF Induces Strong Humoral and Mucosal Immune Responses}

Specific antibodies for rMESF were measured in order to evaluate the humoral immune response. Overall, the immunoglobulins evaluated increase after the first immunization and were maintained over time, showing highly significant differences when compared with the controls PBS+CFA and PBS+alum $(p<0.0001)$. Serum from i.n. immunized mice with rMESF reached the highest levels of IgG and IgG1 after the second immunization (Figures 2B and 3A). However, IgG (Figure 3A) and IgG1 (Figure 2B) in mice that were immunized with rMESF+CFA or rMESF+alum reached the highest levels after the first immunization, and there were no differences in both immunoglobulins between the three experimental groups after the third immunization. Furthermore, maximal peaks of IgG2a were reached by all of the experimental groups after the third immunization (Figure 3C), without significant differences between them.
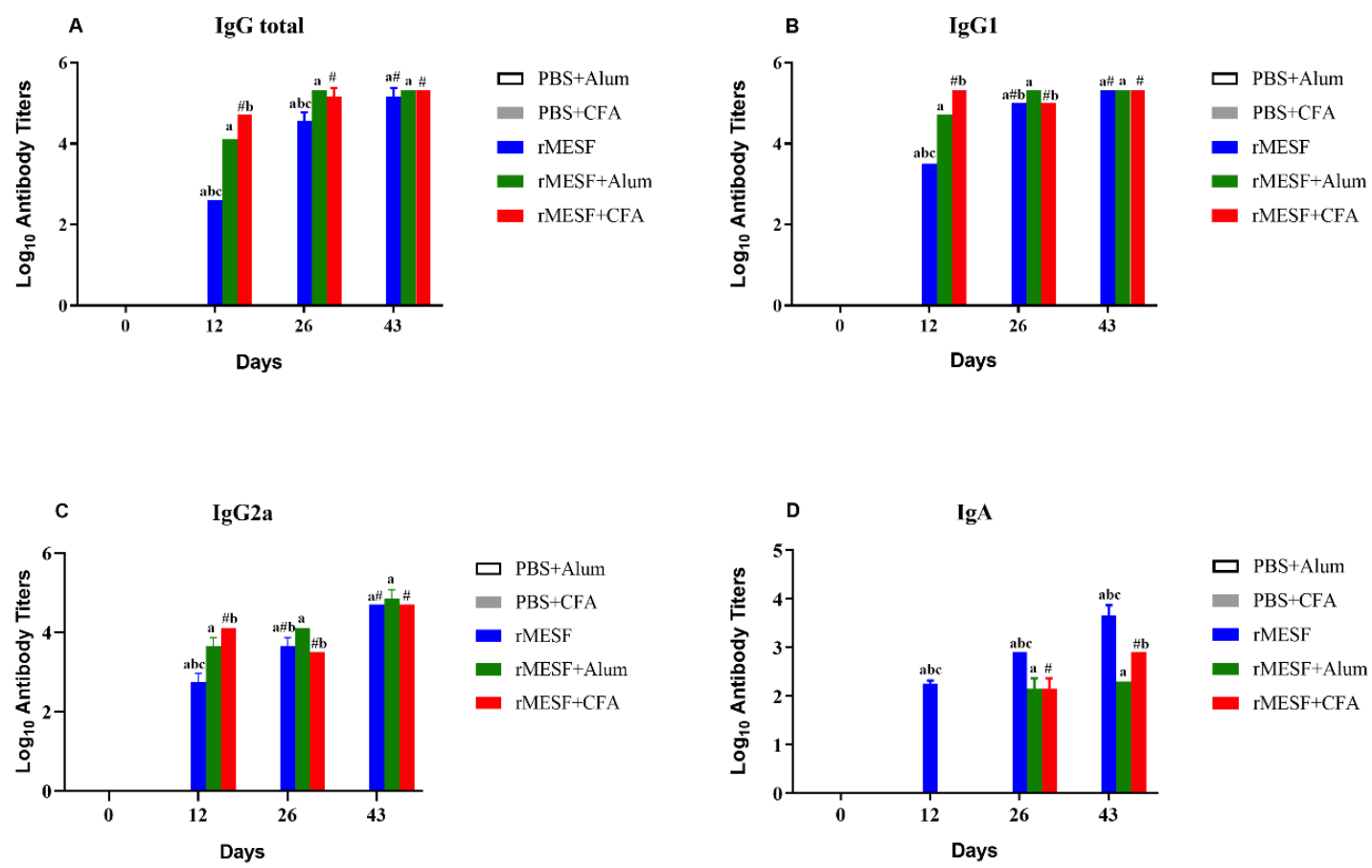

Figure 3. Antibody serum titers in controls and immunized mice. (A) Serum IgG. (B) IgG1. (C) IgG2a. (D) serum IgA. Controls, PBS+alum and PBS+CFA. rMESF+alum groups were immunized intramuscular (i.m.). rMESF +CFA were immunized through intradermic route (i.d.) and the first and second boosters were applied in this group through subcutaneous (s.c.) and i.m. routes, respectively with incomplete Freund's adjuvant (IFA). rMESF groups were immunized with rMESF alone trough intranasal route (i.n.). The two booster doses were given to all experimental mice groups on the 14th and 28th days. Antibody titers were expressed as mean \pm standard deviation (SD) of $\log _{10}$ of the last reciprocal serum dilution above cut-off. Symbols and letters indicate statistically significant values of $p<0.0001$ compared with the respective mice group, \# vs. PBS+CFA, a vs. PBS+alum. b vs. rMESF +alum, c vs. rMESF +CFA. PBS, phosphate-buffered saline. CFA, complete Freund's adjuvant.

Serum IgA and fecal IgA displayed the highest levels in i.n. immunized mice with rMESF alone (Figures 3D and 4, respectively) with highly significant differences $(p<0.0001)$ when compared with the control and rMESF+CFA or rMESF+alum groups. In general, all of the mice groups immunized presented predominant levels of IgG1 and IgG2a following IgA. Antibody titers in the serum and feces of the control animals remained below the limit of detection during the time of evaluation. 


\section{Fecal IgA}

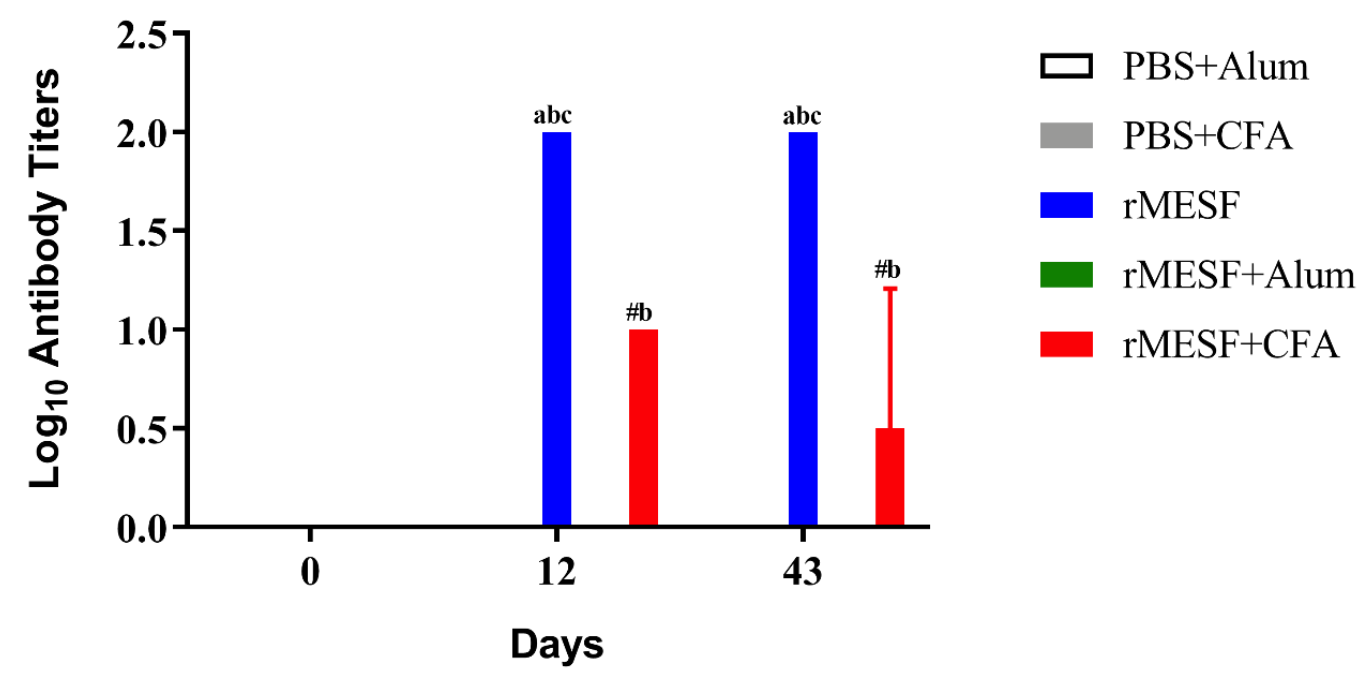

Figure 4. Antibody titers of fecal IgA in controls and immunized mice. Controls, PBS+alum and PBS+CFA. rMESF+alum groups were immunized intramuscular (i.m.). rMESF+CFA were immunized through intradermic route (i.d.) and the first and the second boosters were applied in this group through subcutaneous (s.c.) and i.m. routes, respectively with incomplete Freund's adjuvant (IFA). rMESF groups were immunized with rMESF alone trough intranasal route (i.n.). The two booster doses were given to all experimental mice groups on the 14th and 28th days. Antibody titers were expressed as mean \pm standard deviation (SD) of $\log _{10}$ of the last inverse serum dilution above cut-off. rMESF+alum group remains below the cut-off value calculated, Symbols and letters indicate statistically significant values of $p<0.0001$ as compared with the respective mice group, \# vs. PBS+CFA, a vs. PBS+alum, $\mathrm{b}$ vs. rMESF + alum, c vs. rMESF +CFA. PBS, phosphate-buffered saline. CFA, complete Freund's adjuvant.

\subsection{Multiepitope Protein Elicits a Cytokine Profile}

The cytokine profiles were evaluated from splenocytes cultured with the recombinant chimeric protein. The levels of IL-4 were significantly different $(p<0.0001)$ among all experimental groups and between them compared to the controls PBS+CFA and PBS+alum. However, lower levels of IL-4 were found in mice group i.n. immunized with rMESF alone, and the highest levels were presented in mice immunized with rMESF+alum and rMESF+CFA, respectively (Figure 5A). With respect to TNF- $\alpha$, all of the experimental groups have significantly higher TNF- $\alpha$ levels when compared to the controls ( $p<0.0001$, Figure 5B). The highest levels of TNF- $\alpha$ were found in mice groups immunized with rMESF alone and rMESF+alum with significant difference $(p=0.002)$ between them and mice group immunized with rMESF+CFA. Regarding, IFN- $\gamma$ and IL-17, these significantly increased in all experimental groups when compared with the controls, PBS+CFA and PBS+alum $(p<0.0001$ for INF- $\gamma$ and $p=0.03$ for IL-17), with similar values between all experimental groups (Figure 5C,D). 
A

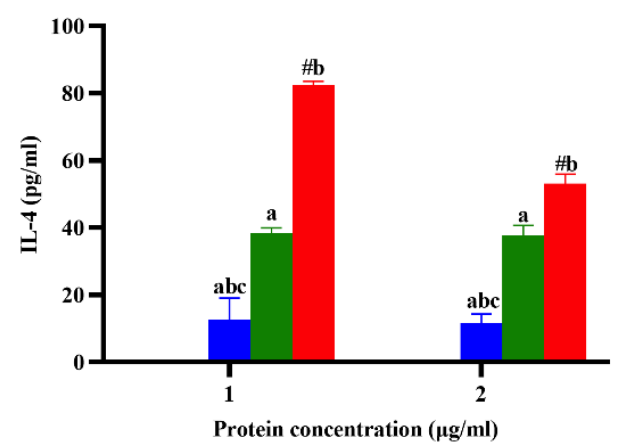

C

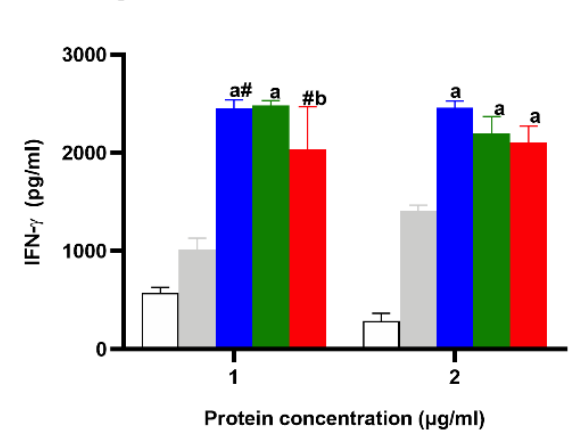

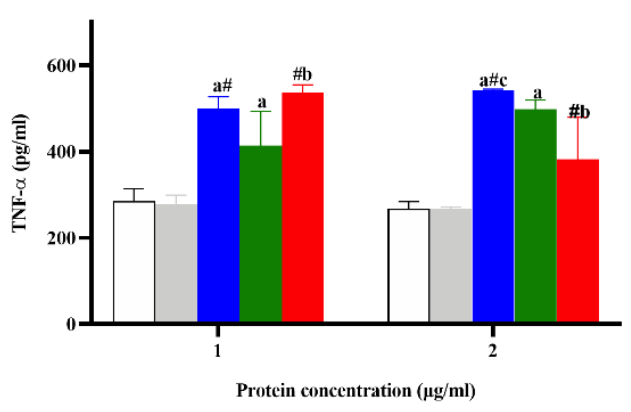

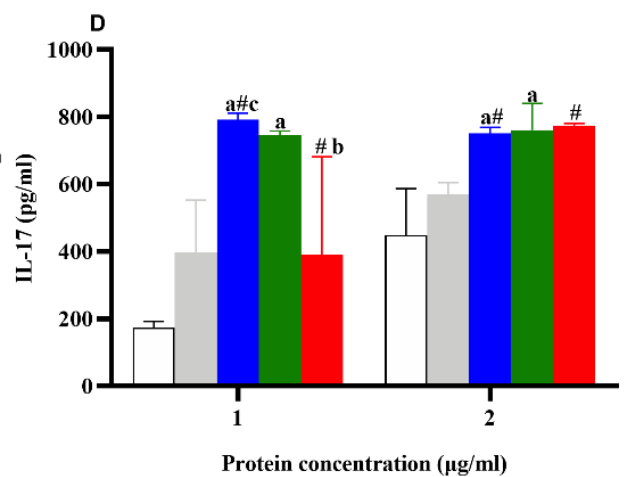

Figure 5. Cytokine levels quantified by ELISA sandwich. Production of (A) IL-4, (B) TNF- $\alpha$, (C) IL-17 and (D) IFN- $\gamma$, present in the supernatant of splenocytes stimulated in vitro with 1 or $2 \mu \mathrm{g} / \mathrm{mL}$ of rMESF multiepitope fusion proteins for $72 \mathrm{~h}$. Splenocytes were collected after 30 days of the last immunization ( $\mathrm{n}=5$ mice/group). The absorbance was measured at $450 \mathrm{~nm}$. Symbols and letters indicate statistically significant values with $p$ values raging from $<0.05$ to 0.0001 (for more details read the text) as compared with the respective mice group. \# vs. PBS+CFA, a vs. PBS+alum, b vs. rMESF+alum, c vs. rMESF+CFA. PBS, phosphate-buffered saline. CFA, complete Freund's adjuvant. Results are plotted as mean \pm standard deviation.

\subsection{Multiepitope Protein Elicits a Strong Lymphoproliferative Response}

The lymphoproliferative response was evaluated on the splenocyte cells. Overall, the experimental immunized groups presented significant differences $(p<0.0001)$ in the lymphoproliferation against the multiepitope protein, compared with the respective controls, PBS+CFA and PBS+alum; there were also significant differences between the experimental groups. The highest levels of lymphoproliferation were found in mice immunized by i.n. route using rMESF alone, followed the mice groups immunized with rMESF+CFA and rMESF+alum adjuvant $(p<0.0001$, Figure 6$)$. All of the control groups did not display a lymphoproliferative response. 


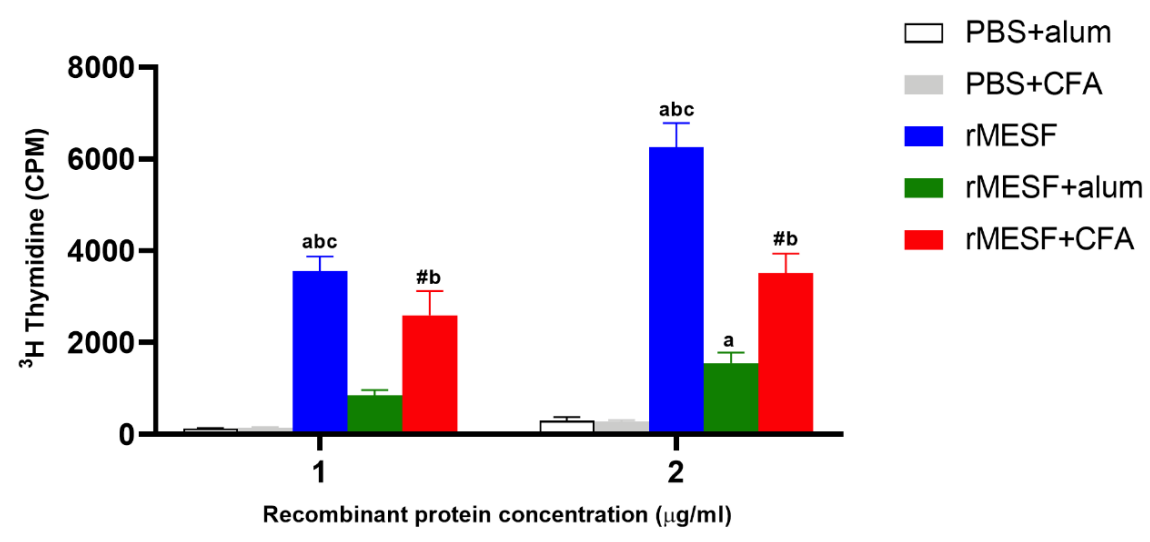

Figure 6. Lymphocyte proliferation. Splenocytes were collected from mice groups ( $\mathrm{n}=5$ mice/group) after 30 days of the last immunization and stimulated in vitro with $1 \mu \mathrm{g} / \mathrm{mL}$ or $2 \mu \mathrm{g} / \mathrm{mL}$ with rMESF multiepitope fusion protein. Symbols and letters indicate statistically significant values of $p<0.0001$ compared with the respective mice group. \# vs. PBS+CFA, a vs. PBS+alum, b vs. rMESF + alum, c vs. rMESF + CFA. PBS, phosphate-buffered saline. CFA, complete Freund's adjuvant. Results are plotted as mean \pm standard deviation.

\subsection{Multiepitope Protein Elicits Protective Response against Shigella Flexneri $2457 T$}

The strong humoral response and cytokines profiles were evaluated for a protective response against S. flexneri. The Kaplan-Meier survival curves showed that mice group i.m. immunized with rMESF+alum showed lower levels of protection, with $20 \%$ survival rate after the pulmonary model infection with S. flexneri. Moreover, the mice group immunized with rMESF+CFA showed $60 \%$ of survival after the infection. However, the highest survival percentage was observed in the group immunized with rMESF alone through i.n. route, where 100\% of mice survived 30 days after the challenge assay (Figure 7). Control mice, PBS+CFA, and PBS+alum died within five days after the challenge assay.

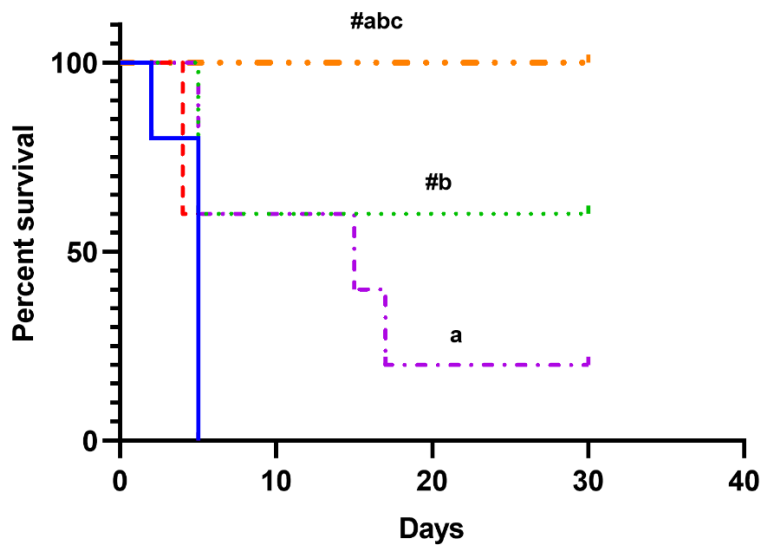

$$
\begin{array}{ll}
\text { - } & \text { PBS+CFA } \\
\text { - ᄂ. } & \text { PBS+alum } \\
\cdots \cdot & \text { rMESF+CFA } \\
-\cdots & \text { rMESF+alum } \\
-\cdots & \text { rMESF }
\end{array}
$$

Figure 7. Protective efficacy of rMESF multiepitope fusion protein immunization on survival. Groups of female BALB/c mice ( $n=5$ mice/group) were immunized through different routes and adjuvant with $25 \mu \mathrm{g} /$ mouse of rMESF. Thirty days after the last booster, mice were challenged with a S. flexneri lethal dose of $1 \times 10^{7} \mathrm{CFU} /$ mouse i.n. Mortality was observed for 30 days. Symbols and letters indicate statistically significant values of $p<0.0001$ compared with the respective mice group. \# vs. PBS+CFA, a vs. PBS+alum b vs. rMESF + alum, c vs. rMESF + CFA. PBS, phosphate-buffered saline. CFA, complete Freund's adjuvant. i.n., intranasally. The protective effect was represented as Kaplan-Meier survival curves. 


\subsection{Organ Burden}

Organ burden studies were performed to determine the bacterial load in the lungs of control and surviving challenge mice in order to evaluate the ability of the chimeric multiepitope protein to promote the clearance of $S$. flexineri. The control groups showed the highest CFU in the lungs, while all of the surviving animals from the experimental groups showed a significant decrease $(p<0.0001)$ in bacterial load when compared to the controls, $<1.3 \times 10^{2} \mathrm{CFU} / \mathrm{mL}$. Furthermore, mice that were immunized with rMESF alone through i.n. route showed the lowest bacterial load in lungs, $<10^{2} \mathrm{CFU} / \mathrm{mL}$, without significant differences between the surviving mice from rMESF+CFA and rMESF+alum groups (Figure 8).

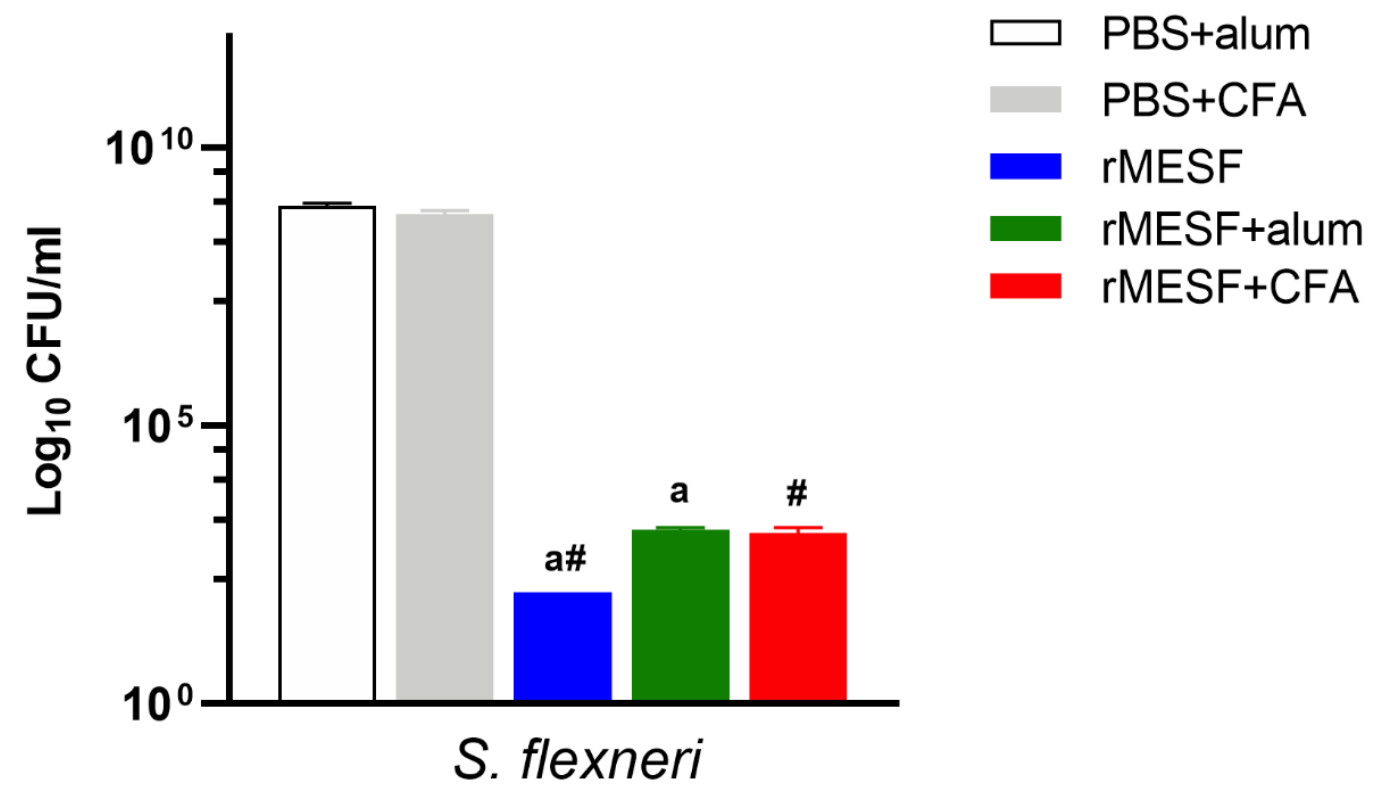

Figure 8. Bacterial burden in lungs after challenge assay of control and immunized mice. Lungs were collected from survival mice and controls groups after 30 days and three days, respectively, of challenge with lethal dose of $S$. flexneri $\left(1 \times 10^{7} \mathrm{CFU} /\right.$ mouse $)$, and bacterial loads were determined by 10 -fold serial dilutions on LB agar plates incubated at $37^{\circ} \mathrm{C}$ for $18 \mathrm{~h}$. Symbols and Letters indicate statistically significant values of $p<0.0001$ compared with the respective mice group. \# vs. PBS+CFA, a vs. PBS+alum. PBS, phosphate-buffered saline. CFA, complete Freund's adjuvant. CFU, colony forming units; i.n., intranasally.

\section{Discussion}

Bacillary dysentery is a global problem that affects children, immunocompromised patients, and elderly generally in developing countries. S. flexneri is one of the most important causing agents of shigellosis, and increasing bacterial antibiotic resistance prompts the development of safe and effective vaccines. Previously, we made an in silico design of a vaccine that contained an adjuvant, HSP-GroEL of $S$. Typhi, fused with highly immunodominant epitopes from the passenger domain of SigA, Pic, and Sap autotransporters proteins of Shigella [16]. The autotransporters that were chosen for the vaccine construction are well conserved in Shigella spp. and other Enterobacteriaceae that affect the human being $[5,35,36]$.

A successful candidate vaccine against Shigella requires the induction of cell-mediated immunity, which plays an essential role in the elimination of these bacteria through the secretion of proinflammatory mediators from innate immune cells and increasing of CD8+ T cells-mediated cytotoxicity and cytokines secreted by CD4+ T cells inducing macrophages activation and the production of antibodies [27,31]. Moreover, the route of administration, the adjuvant and dose of vaccine are correlated with the vaccine 
effectiveness [29]. In this study, a robust humoral immune response induced during and after mice immunization by different routes, measured through IgG, IgG1, and IgG2a production, was strongly increased in all of the experimental groups. However, mice immunized through i.n. route showed a slower increase in the levels of immunoglobulins G compared with other routes. Many vaccines have been shown to confer high levels of protection in mice against Shigella by increased levels of IgG1 and IgG2a isotypes [27,28], as described for this candidate. Nevertheless, levels of systemic and mucosal IgA were increased in all experimental mice groups, with the exception of rMESF+alum mice group, but the highest levels were found in mice immunized through i.n. route. These results support the use of i.n. route for vaccination against Shigella, as it induces both systemic and mucosal immune protection [27,28,37]. In this context, systemic IgA is increased in patients infected with Shigella [38], while the levels of $\operatorname{IgG}$ and $\operatorname{IgA}$ are also increased in patients that naturally acquired immunity against Shigella $[38,39]$. Mucosal IgA is considered one of the most critical immunoglobulins in the clearance of Shigella and preventing reinfection [37]. Therefore, the induction of this antibody is key in the host protection, because IgA anti-LPS and other Shigella antigens interfere with bacterial invasion in the gut, and IgG facilitates the complement-mediated killing and phagocytosis of Shigella [37].

In Shigella infection, several cytokines and T cells population are activated in the host. IL-4, in conjunction with proinflammatory Th1 and Th2 cytokines, are extensively secreted in rectal biopsies from acute and convalescent adult patients with shigellosis that present severe mucosal inflammation [40]. In this work, the secretion of IL-4 varied significantly in all experimental groups, with the lowest levels in mice immunized through i.n. route. This is in accordance with results about the effect of adjuvants on immune response against $S$. Typhi, where IL-4 decreases when GroEL is used alone, compared when it is accompanied with CFA or alum adjuvants [29]. From this point, it could be interesting to know the exact levels of IL-4 that are necessary for an effective vaccine against Shigella and the central role of IL-4 in host protection. Additionally, cells produced high levels of IFN- $\gamma$ in all experimental groups, which is a hallmark of Shigella infection [28,41-43]. IFN- $\gamma$ induced by the vaccine indicates a robust Th1 lymphocyte response, which promotes the production of IgG2a by murine plasma cells [44]. This cytokine has been increasingly found in stool and plasma of convalescent patients compared with the acutely infected adults, which suggests IFN- $\gamma$ plays an important role in the elimination of Shigella cells, being essential to develop an effective protective immunity against shigellosis [45].

Furthermore, the second-highest cytokine secreted was IL-17, which increased in all experimental groups. This cytokine is mainly produced by Th17 cells that are involved in pathogen clearance in mucosal tissues [46,47] and is considered a good indicator of vaccine protective efficacy [31]. In mice, an acute infection with $S$. flexneri induces a dominant Th17 response, playing an important role of secondary immune response that restricts bacterial growth after reinfection in this animal model [48]. Finally, the production of TNF- $\alpha$, a cytokine associated to Th1 immunity was found to be increased in all experimental groups [49]. Nevertheless, the role of TNF- $\alpha$ in the immune response against Shigella is not clear, which is an open field of investigation in host protection against this pathogen.

Interestingly, in this study, the lymphoproliferative response was most potent in mice that were immunized through i.n. route with rMESF alone. This indicates the same recombinant vaccine has different effects depending on routes of vaccination and the adjuvant used. The lowest response was found in mice immunized i.m. with rMESF+alum, which is in accordance with other studies that reported a prominent induction of Th2 type by GroEL+alum with the lowest lymphoproliferative response $[29,50]$. The shift from Th2 to Th1 phenotype was supported with the highest lymphoproliferative response and levels of IFN $-\gamma$ in mice that were immunized with rMESF alone or rMESF+CFA as compared to splenocytes isolated farom mice immunized with rMESF+alum group. Mechanisms of protection against Shigella are not clear, but activation of mucosal immune response is involved in the bacterial neutralization preventing the attachment to and the subsequent invasion of the host epithelial cells [27]. The immunization with HSP as an adjuvant in a fusion protein against HIV or Shigella elicit both humoral and cellular immune responses $[28,51]$. These observations 
demonstrate that vaccines designed with GroEL protein as adjuvant result in high levels of IgG1 and IgG2a or cytokines associated with the Th1 and Th2 immune response, and immunogenicity capacity of providing protection against Shigella $[27,28]$.

Protection against intracellular pathogens requires a dominant Th1-type immunity [52]. This has been demonstrated with $S$. Typhi, an intracellular bacterium, which after immunization using alum adjuvant and GroEL, predominantly induced Th2 types response associated with the lowest protection levels [29]. Similar results were observed in this work, in mice that were immunized with rMESF+alum and rMESF+CFA, which secreted high levels of IL-4. Nevertheless, the low secretion of IL-4 should not be seen as a hallmark for protection, because mice immunized with rMESF+CFA secreted higher levels of IL-4 and better percentages of protection compared to mice immunized with rMESF+alum. Furthermore, i.n. immunization imparted $100 \%$ protection inducing the highest levels of systemic and secretory IgA, indicating a positive effect of this route in the protection against Shigella. Moreover, using GroEL as adjuvant avoids the several side effects that are caused by other adjuvants, such as excessive inflammation, arthritis, and other toxic effects of CFA observed in primates [29,53,54], and it has an advantage over alum adjuvant which only stimulates humoral immunity [55]. Besides, i.n. immunization in Shigella offers the opportunity to induce strong local and systemic protective immunity as it occurs during natural exposure [37]. The protection conferred by the vaccine was observed in the bacterial load in lung tissues, which revealed an enhanced elimination of $S$. flexneri cells, reducing the CFU in all surviving mice that were immunized through different routes compared with the controls. However, as expected, the lowest CFU were found in mice immunized i.n., $<10^{2} \mathrm{CFU} / \mathrm{mL}$. The decreased levels of CFU of Shigella in lung tissues of mice i.n. immunized is related to high levels of protection against Shigella spp. [27,28].

In conclusion, the present study showed that the immunization of mice with rMESF alone or in combination with adjuvants induced both humoral and cell-mediated immune responses. The percentage of protection offered by rMESF+alum (i.m.), rMESF+CFA (s.c.) and rMESFalone (i.n.) is 20,60 , and $100 \%$, respectively. Differences in the protective efficacy were attributed to the nature of immune responses and the route of immunization. This is the first complete in vivo and challenge study using a mix of autotransporter proteins of Shigella fused to GroEL protein in a recombinant vaccine against $S$. flexneri. The results suggest the production of this recombinant vaccine without any adjuvant for preventing shigellosis caused by S. flexneri can be effective. However, the broad-spectrum protective efficacy of our vaccine should be evaluated due to the presence of SigA, Pic, and Sap proteins in Shigella spp. and others E. coli of photogenic importance.

\section{Conclusions}

The importance of using conserved antigens in Shigella such as SigA, Pic and Sap, and the intranasal vaccination and activation of the mucosal immune response are factors that influence the effective protective response against the pathogen. In our vaccine candidate, the protection is mainly related to the increase in immunoglobulin A, and using GroEL adjuvant as inducer of the immune response at the same time, we avoided the adverse effects caused by commercial adjuvants. This vaccine candidate represents an opportunity for the eradication of the major causal agent of shigellosis, Shigella flexneri, as well as a future hopeful candidate in cross protection against other subgroups of Shigella and pathogenic E. coli.

Author Contributions: Conceptualization, Y.L. and A.A.O.; Funding acquisition, A.A.O.; Methodology, Y.L., L.Z., R.E.M., G.O. and M.F.-C.; Project administration, Y.L.; Validation, L.Z. and R.E.M.; Formal analysis, Y.L., R.E.M. and L.A.G.; Investigation, Y.L., L.Z., R.E.M., M.F.-C., J.L.R., G.O. and C.D.-C.; Resources; A.A.O. and L.Z.; Data curation, Y.L. and R.E.M.; Writing-original draft preparation; Y.L.; Writing-review and editing; Y.L., L.A.G., C.D.-C. and A.A.O.; Visualization, Y.L.; Supervision; Y.L. and A.A.O. All authors have read and agreed to the published version of the manuscript.

Funding: This research was funded by Grant 1180122 from the Fondo Nacional de Desarrollo Científico y Tecnológico (FONDECYT), Santiago, Chile. 
Acknowledgments: We thanks to Eleinis Avila-Lovera, Verma Smiriti and Bobby Cherayil for their comments on a version of this manuscript.

Conflicts of Interest: The authors declare no conflict of interest. The funders had no role in the design of the study; in the collection, analyses, or interpretation of data; in the writing of the manuscript, or in the decision to publish the results.

\section{References}

1. Schnupf, P.; Sansonetti, P.J. Shigella Pathogenesis: New Insights through Advanced Methodologies. Microb. Spectr. 2019, 7, 1-24. [CrossRef]

2. Kotloff, K.L.; Winickoff, J.P.; Ivanoff, B.; Clemens, J.D.; Swerdlow, D.L.; Sansonetti, P.J.; Adak, G.K.; Levine, M.M. Global burden of Shigella infections: Implications for vaccine development and implementation of control strategies. Bull World Health Organ. 1999, 77, 651-666. [CrossRef]

3. Nygren, B.L.; Schilling, K.A.; Blanton, E.M.; Silk, B.J.; Cole, D.J.; Mintz, E.D. Foodborne outbreaks of shigellosis in the USA, 1998-2008. Epidemiol. Infect. 2013, 141, 233-241. [CrossRef]

4. Kozyreva, V.K.; Jospin, G.; Greninger, A.L.; Watt, J.P.; Eisen, J.A.; Chaturvedi, V. Recent Outbreaks of Shigellosis in California Caused by Two Distinct Populations of Shigella sonnei with either Increased Virulence or Fluoroquinolone Resistance. mSphere 2016, 1, e00344-16. [CrossRef]

5. Oany, A.R.; Pervin, T.; Mia, M.; Hossain, M.; Shahnaij, M.; Mahmud, S.; Kibria, K.M.K. Vaccinomics Approach for Designing Potential Peptide Vaccine by Targeting Shigella spp. Serine Protease Autotransporter Subfamily Protein SigA. J. Immunol Res. 2017, 2017, 6412353. [CrossRef]

6. Troeger, C.; Forouzanfar, M.; Rao, P.C.; Khalil, I.; Brown, A.; Reiner, R.C.; Fullman, N.; Thompson, R.L.; Abajobir, A.; Ahmed, M.; et al. Estimates of global, regional, and national morbidity, mortality, and aetiologies of diarrhoeal diseases: A systematic analysis for the Global Burden of Disease Study 2015. Lancet Infect. Dis. 2017, 17, 909-948. [CrossRef]

7. Khalil, I.A.; Troeger, C.; Blacker, B.F.; Rao, P.C.; Brown, A.; Atherly, D.E.; Brewer, T.G.; Engmann, C.M.; Houpt, E.R.; Kang, G.; et al. Morbidity and mortality due to Shigella and enterotoxigenic Escherichia coli diarrhoea: The Global Burden of Disease Study 1990-2016. Lancet Infect. Dis. 2018, 18, 1229-1240. [CrossRef]

8. Taneja, N.; Mewara, A.; Kumar, A.; Verma, G.; Sharma, M. Cephalosporin-resistant Shigella flexneri over 9 years (2001-09) in India. J. Antimicrob. Chemother. 2012, 67, 1347-1353. [CrossRef]

9. Sjölund Karlsson, M.; Bowen, A.; Reporter, R.; Folster, J.P.; Grass, J.E.; Howie, R.L.; Taylor, J.; Whichard, J.M. Outbreak of infections caused by Shigella sonnei with reduced susceptibility to azithromycin in the United States. Antimicrob. Agents Chemother. 2013, 57, 1559-1560. [CrossRef]

10. Jennison, A.V.; Verma, N.K. Shigella flexneri infection: Pathogenesis and vaccine development. FEMS Microbiol. Rev. 2004, 28, 43-58. [CrossRef]

11. Livio, S.; Strockbine, N.A.; Panchalingam, S.; Tennant, S.M.; Barry, E.M.; Marohn, M.E.; Antonio, M.; Hossain, A.; Mandomando, I.; Ochieng, J.B.; et al. Shigella Isolates from the Global Enteric Multicenter Study Inform Vaccine Development. Clin. Infect. Dis. 2014, 59, 933-941. [CrossRef] [PubMed]

12. Venkatesan, M.M.; Ranallo, R.T. Live-attenuated Shigella vaccines. Expert. Rev. Vaccines 2006, 5, 669-686. [CrossRef] [PubMed]

13. Ashkenazi, S.; Cohen, D. An update on vaccines against Shigella. Ther. Adv. Vaccines 2013, 1, $113-123$. [CrossRef]

14. Kaminski, R.W.; Oaks, E.V. Inactivated and subunit vaccines to prevent shigellosis. Expert. Rev. Vaccines 2009, 8, 1693-1704. [CrossRef]

15. Barry, E.M.; Pasetti, M.F.; Sztein, M.B.; Fasano, A.; Kotloff, K.L.; Levine, M.M. Progress and pitfalls in Shigella vaccine research. Nat. Rev. Gastroenterol. Hepatol. 2013, 10, 245-255. [CrossRef]

16. León, Y.; Zapata, L.; Salas-Burgos, A.; Oñate, A. In silico design of a vaccine candidate based on autotransporters and HSP against the causal agent of shigellosis, Shigella flexneri. J. Mol. Immunol. 2020, 121, 47-58. [CrossRef]

17. Al-Hasani, K.; Henderson, I.R.; Sakellaris, H.; Rajakumar, K.; Grant, T.; Nataro, J.P.; Robins-Browne, R.; Adler, B. The sigA Gene Which Is Borne on the she Pathogenicity Island of Shigella flexneri 2a Encodes an Exported Cytopathic Protease Involved in Intestinal Fluid Accumulation. Infect. Immun. 2000, 68, 2457-2463. [CrossRef] 
18. Al-Hasani, K.; Navarro-Garcia, F.; Huerta, J.; Sakellaris, H.; Adler, B. The immunogenic SigA enterotoxin of Shigella flexneri 2a binds to HEp-2 cells and induces fodrin redistribution in intoxicated epithelial cells. PLoS ONE 2009, 4, e8223. [CrossRef]

19. Ruiz-Perez, F.; Wahid, R.; Faherty, C.S.; Kolappaswamy, K.; Rodriguez, L.; Santiago, A.; Murphy, E.; Cross, A.; Sztein, M.B.; Nataro, J.P. Serine protease autotransporters from Shigella flexneri and pathogenic Escherichia coli; target a broad range of leukocyte glycoproteins. Proc. Natl. Acad. Sci. USA 2011, 108, 12881-12886. [CrossRef]

20. Bellini, E.M.; Elias, W.P.; Gomes, T.A.T.; Tanaka, T.L.; Taddei, C.R.; Huerta, R.; Navarro-Garcia, F.; Martinez, M.B. Antibody response against plasmid-encoded toxin (Pet) and the protein involved in intestinal colonization (Pic) in children with diarrhea produced by enteroaggregative Escherichia coli. FEMS Immunol. Med. Microbiol. 2005, 43, 259-264. [CrossRef]

21. Woude, M.W.v.d.; Henderson, I.R. Regulation and Function of Ag43 (Flu). Annu. Rev. Microbiol. 2008, 62, 153-169. [CrossRef] [PubMed]

22. Zügel, U.; Kaufmann, S.H.E. Role of Heat Shock Proteins in Protection from and Pathogenesis of Infectious Diseases. Clin. Microbiol. Rev. 1999, 12, 19-39. [CrossRef]

23. Vabulas, R.M.; Ahmad-Nejad, P.; da Costa, C.; Miethke, T.; Kirschning, C.J.; Häcker, H.; Wagner, H. Endocytosed HSP60s Use Toll-like Receptor 2 (TLR2) and TLR4 to Activate the Toll/Interleukin-1 Receptor Signaling Pathway in Innate Immune Cells. J. Biol. Chem. 2001, 276, 31332-31339. [CrossRef]

24. Lindler, L.E.; Hayes, J.M. Nucleotide sequence of the Salmonella typhi groEL heat shock gene. Microb. Pathog. 1994, 17, 271-275. [CrossRef]

25. Paliwal, P.K.; Bansal, A.; Sagi, S.S.K.; Mustoori, S.; Govindaswamy, I. Cloning, expression and characterization of heat shock protein 60 (groEL) of Salmonella enterica serovar Typhi and its role in protective immunity against lethal Salmonella infection in mice. Clin. Immunol. 2008, 126, 89-96. [CrossRef]

26. Chitradevi, S.T.S.; Kaur, G.; Singh, K.; Sugadev, R.; Bansal, A. Recombinant heat shock protein 60 (Hsp60/GroEL) of Salmonella enterica serovar Typhi elicits cross-protection against multiple bacterial pathogens in mice. Vaccine 2013, 31, 2035-2041. [CrossRef]

27. Chitradevi, S.T.S.; Kaur, G.; Uppalapati, S.; Yadav, A.; Singh, D.; Bansal, A. Co-administration of rIpaB domain of Shigella with rGroEL of S. Typhi enhances the immune responses and protective efficacy against Shigella infection. Cell Mol. Immunol. 2015, 12, 757-767. [CrossRef]

28. Chitradevi, S.T.S.; Kaur, G.; Sivaramakrishna, U.; Singh, D.; Bansal, A. Development of recombinant vaccine candidate molecule against Shigella infection. Vaccine 2016, 34, 5376-5383. [CrossRef]

29. Bansal, A.; Paliwal, P.K.; Sagi, S.S.K.; Sairam, M. Effect of adjuvants on immune response and protective immunity elicited by recombinant Hsp60 (GroEL) of Salmonella typhi against $S$. typhi infection. Mol. Cell Biochem. 2010, 337, 213-221. [CrossRef]

30. Frey, A.; Di Canzio, J.; Zurakowski, D. A statistically defined endpoint titer determination method for immunoassays. J. Immunol. Methods 1998, 221, 35-41. [CrossRef]

31. Martinez-Becerra, F.J.; Scobey, M.; Harrison, K.; Choudhari, S.P.; Quick, A.M.; Joshi, S.B.; Middaugh, C.R.; Picking, W.L. Parenteral immunization with IpaB/IpaD protects mice against lethal pulmonary infection by Shigella. Vaccine 2013, 31, 2667-2672. [CrossRef]

32. Gómez, L.; Llanos, J.; Escalona, E.; Sáez, D.; Álvarez, F.; Molina, R.; Flores, M.; Oñate, A. Multivalent Fusion DNA Vaccine against Brucella abortus. Biomed. Res. Int. 2017, 6535479. [CrossRef] [PubMed]

33. Escalona, E.; Sáez, D.; Oñate, A. Immunogenicity of a Multi-Epitope DNA Vaccine Encoding Epitopes from $\mathrm{Cu}-\mathrm{Zn}$ Superoxide Dismutase and Open Reading Frames of Brucella abortus in Mice. Front. Immunol. 2017, 8, 125. [CrossRef] [PubMed]

34. Mallett, C.P.; VanDeVerg, L.; Collins, H.H.; Hale, T.L. Evaluation of Shigella vaccine safety and efficacy in an intranasally challenged mouse model. Vaccine 1993, 11, 190-196. [CrossRef]

35. Abreu, A.G.; Fraga, T.R.; Granados Martínez, A.P.; Kondo, M.Y.; Juliano, M.A.; Juliano, L.; Navarro-Garcia, F.; Isaac, L.; Barbosa, A.S.; Elias, W.P. The Serine Protease Pic from Enteroaggregative Escherichia coli Mediates Immune Evasion by the Direct Cleavage of Complement Proteins. J. Infect. Dis. 2015, 212, 106-115. [CrossRef] [PubMed]

36. Zalewska-Piatek, B.; Piatek, R.; Olszewski, M.; Kur, J. Identification of antigen Ag43 in uropathogenic Escherichia coli Dr+ strains and defining its role in the pathogenesis of urinary tract infections. Microbiology 2015, 161, 1034-1049. [CrossRef] 
37. Pasetti, M.F.; Venkatesan, M.M.; Barry, E.M. Chapter 30-Oral Shigella Vaccines. In Mucosal Vaccines, 2nd ed.; Kiyono, H., Pascual, D.W., Eds.; Academic Press: Cambridge, MA, USA, 2020; pp. 515-536. [CrossRef]

38. Islam, D.; Wretlind, B.; Ryd, M.; Lindberg, A.A.; Christensson, B. Immunoglobulin subclass distribution and dynamics of Shigella-specific antibody responses in serum and stool samples in shigellosis. Infect Immun. 1995, 63, 2054-2061. [CrossRef]

39. Islam, D.; Veress, B.; Bardhan, P.K.; Lindberg, A.A.; Christensson, B. Quantitative assessment of IgG and IgA subclass producing cells in rectal mucosa during shigellosis. J. Clin. Pathol. 1997, 50, 513. [CrossRef]

40. Raqib, R.; Lindberg, A.A.; Wretlind, B.; Bardhan, P.K.; Andersson, U.; Andersson, J. Persistence of local cytokine production in shigellosis in acute and convalescent stages. Infect. Immun. 1995, 63, 289-296. [CrossRef]

41. Le-Barillec, K.; Magalhaes, J.G.; Corcuff, E.; Thuizat, A.; Sansonetti, P.J.; Phalipon, A.; Di Santo, J.P. Roles for T and NK Cells in the Innate Immune Response to Shigella flexneri. J. Immunol. 2005, 175, 1735-1740. [CrossRef]

42. Martinez-Becerra, F.J.; Kissmann, J.M.; Diaz-McNair, J.; Choudhari, S.P.; Quick, A.M.; Mellado-Sanchez, G.; Clements, J.D.; Pasetti, M.F.; Picking, W.L. Broadly Protective Shigella Vaccine Based on Type III Secretion Apparatus Proteins. Infect. Immun. 2012, 80, 1222-1231. [CrossRef] [PubMed]

43. Nag, D.; Sinha, R.; Mitra, S.; Barman, S.; Takeda, Y.; Shinoda, S.; Chakrabarti, M.K.; Koley, H. Heat killed multi-serotype Shigella immunogens induced humoral immunity and protection against heterologous challenge in rabbit model. Immunobiology 2015, 220, 1275-1283. [CrossRef] [PubMed]

44. Finkelman, F.D.; Katona, I.M.; Mosmann, T.R.; Coffman, R.L. IFN-gamma regulates the isotypes of Ig secreted during in vivo humoral immune responses. J. Immunol. 1988, 140, 1022-1027.

45. Raqib, R.; Wretlind, B.; Andersson, J.; Lindberg, A.A. Cytokine Secretion in Acute Shigellosis Is Correlated to Disease Activity and Directed More to Stool than to Plasma. J. Infect. Dis. 1995, 171, 376-384. [CrossRef] [PubMed]

46. Ishigame, H.; Kakuta, S.; Nagai, T.; Kadoki, M.; Nambu, A.; Komiyama, Y.; Fujikado, N.; Tanahashi, Y.; Akitsu, A.; Kotaki, H.; et al. Differential Roles of Interleukin-17A and -17F in Host Defense against Mucoepithelial Bacterial Infection and Allergic Responses. Immunity 2009, 30, 108-119. [CrossRef]

47. Curtis, M.M.; Way, S.S. Interleukin-17 in host defense against bacterial, mycobacterial and fungal pathogens. Immunology 2009, 126, 177-185. [CrossRef]

48. Sellge, G.; Magalhaes, J.G.; Konradt, C.; Fritz, J.H.; Salgado-Pabon, W.; Eberl, G.; Bandeira, A.; Di Santo, J.P.; Sansonetti, P.J.; Phalipon, A. Th17 Cells Are the Dominant T Cell Subtype Primed by Shigella flexneri Mediating Protective Immunity. J. Immunol. 2010, 184, 2076-2085. [CrossRef]

49. Kisuya, J.; Chemtai, A.; Raballah, E.; Keter, A.; Ouma, C. The diagnostic accuracy of Th1 (IFN- $\gamma$, TNF- $\alpha$, and IL-2) and Th2 (IL-4, IL-6 and IL-10) cytokines response in AFB microscopy smear negative PTB- HIV co-infected patients. Sci. Rep. 2019, 9, 2966. [CrossRef]

50. Cribbs, D.H.; Ghochikyan, A.; Vasilevko, V.; Tran, M.; Petrushina, I.; Sadzikava, N.; Babikyan, D.; Kesslak, P.; Kieber-Emmons, T.; Cotman, C.W.; et al. Adjuvant-dependent modulation of Th1 and Th2 responses to immunization with $\beta$-amyloid. Int. Immunol. 2003, 15, 505-514. [CrossRef]

51. Suzue, K.; Young, R.A. Adjuvant-free hsp70 fusion protein system elicits humoral and cellular immune responses to HIV-1 p24. J. Immunol. 1996, 156, 873-879.

52. Jo, S.H.; Lee, J.; Park, E.; Kim, D.W.; Lee, D.H.; Ryu, C.M.; Choi, D.; Park, J.M. A human pathogenic bacterium Shigella proliferates in plants through adoption of type III effectors for shigellosis. Plant Cell Environ. 2019, 42, 2962-2978. [CrossRef] [PubMed]

53. Broderson, J.R. A retrospective review of lesions associated with the use of Freund's adjuvant. Lab. Anim. Sci. 1989, 39, 400-405.

54. Bennett, B.; Check, I.J.; Olsen, M.R.; Hunter, R.L. A comparison of commercially available adjuvants for use in research. J. Immunol. Methods 1992, 153, 31-40. [CrossRef]

55. Allison, A.C.; Byars, N.E. Immunological adjuvants: Desirable properties and side-effects. Mol. Immunol. 1991, 28, 279-284. [CrossRef]

(C) 2020 by the authors. Licensee MDPI, Basel, Switzerland. This article is an open access article distributed under the terms and conditions of the Creative Commons Attribution (CC BY) license (http://creativecommons.org/licenses/by/4.0/). 